\title{
Outcomes of hybrid and Norwood Stage I procedures for the treatment of hypoplastic left heart syndrome and its variants
}

\author{
Hipoplastik sol kalp sendromu ve varyantlarının tedavisinde hibrit ve \\ Norwood Aşama I işlemlerinin sonuçları
}

\section{Ersin Erek' (D), Selim Aydın' (D), Bahar Temur' ${ }^{(D)}$, Mehmet Akif Önalan' ${ }^{\mathbb{D}}$, Dilek Suzan² (D), Müzeyyen İyigün ${ }^{3}$ (D) ibrahim Halil Demir ${ }^{4}$ D, Ender Ödemiş ${ }^{5}$ (D)}

\author{
Institution where the research was done: \\ Acıbadem Mehmet Ali Aydınlar University School of Medicine, Istanbul, Turkey
}

\author{
Author Affiliations: \\ 'Department of Cardiovascular Surgery, Acıbadem Mehmet Ali Aydınlar University School of Medicine, Istanbul, Turkey \\ 2Department of Cardiovascular Surgery, Marie Lannelongue Hospital, Paris, France \\ ${ }^{3}$ Department of Anesthesiology and Reanimation, Acıbadem Mehmet Ali Aydınlar University School of Medicine, Istanbul, Turkey \\ ${ }^{4}$ Department of Pediatric Cardiac Surgery, Medicana International Hastanesi, Istanbul, Turkey \\ ${ }^{5}$ Department of Pediatric Cardiology, Acıbadem Mehmet Ali Aydınlar University School of Medicine, Istanbul, Turkey
}

\begin{abstract}
Background: In this study, we present the outcomes of hybrid and Norwood Stage I procedures for the treatment of hypoplastic left heart syndrome and its variants.

Methods: In this study, a total of 97 pediatric patients who were operated due to hypoplastic left heart syndrome and its variants between March 2011 and October 2018 were retrospectively analyzed. Thirty-two of the patients (28 males, 4 females; median age 5 days; range, 1 to 25 days) underwent Norwood Stage I operation (Group N), while the remaining 65 patients (44 males, 21 females; median age 6 days; range, 1 to 55 days) underwent a hybrid procedure (Group H). Both treatment strategies were compared.

Results: The median body weight in Group $\mathrm{H}$ was significantly lower and the number of patients with a low birth weight $(<2,500 \mathrm{~g})$ was significantly higher than Group N ( $\mathrm{p}=0.002$ and 0.004 , respectively). The postoperative early mortality rate was similar between the groups. Univariate and multivariate analyses revealed that the need for preoperative mechanical ventilation was a significant factor for mortality ( $\mathrm{p}=0.004$ and 0.003 , respectively). Syndromic appearance was also a significant factor the multivariate analysis $(p=0.03)$. There was a statistically significant difference between the groups in terms of the inter-stage mortality rates $(\mathrm{p}=0.0045)$. Second-stage procedure was performed in 32 patients. The early mortality rate after the Glenn operation was $7.6 \%$. Six patients died after comprehensive Stage II operation. Five patients underwent biventricular repair and 8 patients had third-stage fenestrated extracardiac Fontan operation (Group N, n=7 and Group H, n=1). The Kaplan-Meier survival curve demonstrated that Group $\mathrm{N}$ had a higher survival rate at both one and five years than Group $\mathrm{H}$, although the difference was not statistically significant $(\mathrm{p}=0.15)$. Subgroup analysis showed that the Norwood procedure with Sano modification had the highest survival rate with $40 \%$ at five years.

Conclusion: Our study results show that patients undergoing the Norwood procedure have a more uneventful course of inter-stage period and Stage II and III, despite drawbacks early after Stage I procedure. Based on our experiences, we recommend performing the hybrid intervention in patients with a poor clinical condition and a body weight of $<2,500 \mathrm{~g}$.

Keywords: Congenital heart anomalies, hypoplastic left heart syndrome, neonate, Norwood operation, palliative surgery.
\end{abstract}

$\ddot{O} Z$

Amaç: Bu çalışmada, hipoplastik sol kalp sendromu ve varyantlarının tedavisinde hibrit ve Norwood Aşama I işlemlerinin sonuçları sunuldu.

Calışma planı: Bu çalışmada Mart 2011-Ekim 2018 tarihleri arasında hipoplastik sol kalp sendromu veya varyantları nedeniyle ameliyat edilen toplam 97 pediatrik hasta retrospektif olarak değerlendirildi. Hastaların 32'sine (28 erkek, 4 kız; medyan yaş 5 gün; dağılım 1-25 gün) Norwood Aşama I ameliyatı (Grup N) yapılırken, geriye kalan 65 hastaya (44 erkek, 21 kız; medyan yaş 6 gün; dağılım 1-55 gün) hibrit Aşama I ameliyatı (Grup H) uygulandı. Her iki tedavi stratejisi karşılaştırıldı.

Bulgular: Grup N'ye kıyasla Grup H'nin medyan kilosu anlamlı düzeyde daha düşük olup, düşük doğum ağırlığı (<2500 g) olan hasta sayısı anlamlı düzeyde daha yüksek idi. Ameliyat sonrası erken mortalite gruplar arasında benzerdi. Tek değişkenli ve çok değişkenli analizler, ameliyat öncesi mekanik ventilasyon ihtiyacının mortalite açısından anlamlı bir faktör olduğunu gösterdi (sırasıyla, $\mathrm{p}=0.004$ ve 0.003 ). Sendromik görünüm de, çok değişkenli analizde anlamlı bir faktör idi $(\mathrm{p}=0.03)$. Aşamalar arasında mortalite oranları açısından gruplar arasında istatistiksel olarak anlamlı bir fark vardı. Toplam 32 hastaya ikinci aşama işlem uygulandı. Glenn ameliyatı sonrasında erken mortalite oranı \%7.6 idi. Kapsamlı Aşama II operasyonu sonrasında altı hasta kaybedildi. Beş hastaya biventriküler tamir ve 8 hastaya üçüncü aşama fenestre ekstrakardiyak Fontan ameliyatı yapıldı (Grup N, n=7 ve Grup H, n=1). Kaplan-Meier sağkalım eğrisi, sağkalım oranının hem bir hem de beşinci yıllarda Grup H'ye kıyasla Grup N'de daha yüksek olduğunu göstermekle birlikte, fark istatistiksel olarak anlamlı değildi $(\mathrm{p}=0.15)$. Alt grup analizi, Sano modifikasyonu ile birlikte Norwood işleminin beşinci yılda \%40 ile en yüksek sağkalım oranına sahip olduğunu gösterdi.

Sonuç: Çalışma sonuçlarımız, Aşama I işlemi sonrasında erken dönemde görülen zorluklara rağmen, Norwood işlemi yapılan hastaların aşamalar arası dönemde ve Aşama II ve III'te daha sorunsuz bir seyir izlediğini göstermektedir. Deneyimlerimize dayanarak, klinik durumu kötü olan ve kilosu $<2500 \mathrm{~g}$ olan hastalarda hibrit girişim yapılmasını önermekteyiz.

Anahtar sözcükler: Konjenital kalp anomalileri, hipoplastik sol kalp sendromu, yenidoğan, Norwood operasyonu, palyatif cerrahi.

Received: August 24, 2019 Accepted: January 05, 2020 Published online: April 22, 2020

Correspondence: Ersin Erek, MD. Acıbadem Atakent Hastanesi, Kalp ve Damar Cerrahisi Kliniği, 34303 Küçükçekmece, İstanbul, Türkiye. Tel: +90 212 - 4044278 e-mail: ersinerek@gmail.com syndrome and its variants. Turk Gogus Kalp Dama 2020;28(2):282-293 
Hypoplastic left heart syndrome (HLHS) and its variants are one of the most difficult congenital heart anomalies to manage surgically. Although compassionate care or heart transplantation are options for some centers and countries, eventual Fontan tract is the current management strategy in many centers. $^{[1,2]}$ Despite considerable improvements have been achieved in Norwood Stage I procedure owing to the improvements in intensive care unit facilities and some surgical modifications such as Sano shunt, beating heart techniques, and Dunk technique in the last two decades, early mortality still remains as high as 20 to $40 \%$ with significant morbidity. ${ }^{[1-4]}$ The hybrid procedure (placement of bilateral pulmonary artery [PA] bands and a ductal stent with or without atrial septal manipulation) has emerged in the last decades as an alternative to Stage I palliation for neonates with HLHS ${ }^{[5]}$ The early success with the hybrid approach reported by Akintürk et al. ${ }^{[6]}$ and Galantowicz et al. ${ }^{[7]}$ have prompted the increasing use of this strategy to minimize the deleterious impact of the conventional surgical intervention in high-risk patients. ${ }^{[8]}$ The initial experiences reported high mortality and morbidity, mainly due to learning curve and patient selection. ${ }^{[9,10]}$

To date, although no significant survival benefit of the hybrid approach over the conventional Norwood Stage I procedure has been reported, hybrid palliation is usually considered an appropriate alternative, particularly in high-risk patients with HLHS. ${ }^{[10,11]}$ In this study, we present the outcomes of hybrid and Norwood Stage I procedures for the treatment of HLHS and its variants to shed light into the most optimal surgical strategy for the management of this difficult subset of patients.

\section{PATIENTS AND METHODS}

In this retrospective study, a total of 97 pediatric patients who were operated due to HLHS and its variants between March 2011 and October 2018 were included. Thirty-two of the patients $(28$ males, 4 females; median age 5 days; range, 1 to 25 days) underwent Norwood Stage I operation (Group N), while the remaining 65 patients (44 males, 21 females; median age 6 days; range, 1 to 55 days) underwent a hybrid procedure (Group $\mathrm{H}$ ) as the first-line palliation. Half of the patients $(n=16)$ in Group $N$ had Sano modification and the others $(n=16)$ had right innominate artery-to-right PA shunt for the maintenance of pulmonary circulation. Fifty-four patients in Group $\mathrm{H}$ underwent bilateral banding alone, while the remaining 11 patients had associated atrial septectomy with a short period of cardiopulmonary bypass (CPB) due to restrictive interatrial septal communication.
The patient's preference was considered depending on the general condition of the patient and clinical experience of the surgeon. A written informed consent was obtained from each parent. The study protocol was approved by the Acıbadem Mehmet Ali Aydınlar University (ATADEK) Ethics Committee. The study was conducted in accordance with the principles of the Declaration of Helsinki.

\section{Surgical and Interventional Techniques}

\section{Hybrid Stage Ia: Bilateral PA banding}

Under general anesthesia, median sternotomy was done. Right and left lobes of the thymus were separated and left in situ. Upper half of the pericardium was opened and hanged by two stay sutures. The bands were fashioned by cutting a $2-\mathrm{mm}$ ring from a $3.5-\mathrm{mm}$ expanded polytetrafluoroethylene (ePTFE) tube graft. Without extensive dissection, right and left PAs were encircled with a right-angle clamp. Bands were passed around it and tightened with a $6 / 0$ propylene suture. They were, then, tacked to the local adventitia to prevent distal migration. The target was an increase in systemic systolic blood pressure by $10 \mathrm{mmHg}$ and fall in oxygen saturation by $10 \%$. We always used 3.5-mm PTFE strips for all patients; however, we arranged the tightness of the bands by taking deep or swallow bites of sutures. Inotropic infusions (milrinone $0.5 \mu \mathrm{g} / \mathrm{kg} / \mathrm{min}$ and adrenaline $0.03 \mu \mathrm{g} / \mathrm{kg} / \mathrm{min}$ ) were initiated in advance in addition to prostaglandin E1 (PGE1) perfusion. In 11 patients, additional surgical atrial septectomy was performed due to restricted atrial septal communication. The PA and bicaval cannulations were done. During normothermia, in cases with aortic atresia, proximal main PA was encircled and clamped. Atriotomy was performed on a beating heart. Atrial septectomy was done. After deairing, the PA clamp was removed and the patients were weaned from CPB.

\section{Hybrid Stage Ib: Ductus arteriosus stenting}

A couple of days following PA banding, the patients were taken to the cardiac catheterization laboratory. The procedure was usually done under deep sedation without endotracheal intubation. A biplane angiography was usually preferred. After femoral venous access, the angiogram was done in two projections (lateral and right anterior oblique $40^{\circ}$ ) to delineate the anatomical details of the ductus arteriosus. The length and the narrowest part of the ductus were measured. A stent was selected larger than the narrowest part of the ductus and longer than the length of the ductus. In general, in patients with ductus-dependent systemic circulation, the ductus diameter was larger than those 
with pulmonary atresia. Therefore, peripheral stents (Omnilink ${ }^{\circledR}$ Abbott Laboratories, Abbott Park, IL, USA) were often used for stenting. Ductus arteriosus was crossed with a delivery wire from the PA to the descending aorta. The stent was advanced through the femoral vein by means of the main PA into the ductus arteriosus. After confirming the correct location, the stent was deployed. Echocardiographic examination confirmed the correct implantation. After stent implantation, heparin infusion was continued in $15 \mathrm{U} / \mathrm{kg} / \mathrm{h}$ for $24 \mathrm{~h}$. Subsequently, acetylsalicylic acid was started at a dose of $5 \mathrm{mg} / \mathrm{kg}$, until the second operation.

\section{Hybrid Stage Ic: Atrial septal stenting}

The femoral venous approach was used. The atrial septum was crossed with a wire from the right atrium to the left, and the wire was positioned in a pulmonary vein. A balloon-expandable stent, which was usually larger than $8 \mathrm{~mm}$, was advanced through the long sheath up to the atrial septum. The length of the stent was usually shorter than the total atrial length. The stent was, then, centralized. The sheath was withdrawn and the stent was uncovered. After control angiograms and echocardiographic examinations, the stent was implanted.

\section{Comprehensive Norwood Stage II}

Under general anesthesia, resternotomy was performed. The aortic arch, brachiocephalic vessels, ductus arteriosus, descending aorta, and PAs were all dissected and encircled before beginning of CPB. In cases in whom direct innominate artery cannulation was not feasible, a 3.5-mm PTFE graft was anastomosed to the innominate artery and used for arterial inflow. Both caval veins were cannulated separately and $\mathrm{CPB}$ was initiated. During moderate hypothermia $\left(28^{\circ} \mathrm{C}\right)$, the aortic arch was clamped distal to the innominate artery. The left carotid and the left subclavian arteries were clamped with temporary Yasargil neurovascular mini-clips. A side clamp was applied to the descending aorta 1-2 $\mathrm{cm}$ distal to the ductus arteriosus. Selective cerebral and coronary perfusion was started with 40 to $50 \mathrm{~mL} / \mathrm{kg}$ flow, while monitoring the right radial artery pressure and near-infrared spectroscopy values. While the heart was perfused, the descending aorta was transected just below the ductal stent. The ductus arteriosus was resected with its stent. The aortic arch was longitudinally opened from the distal end to the aortic arch clamp. Half of the descending aorta was sutured to the distal aortic arch. The rest of the aortic arch reconstruction was performed with a generous patch of bovine pericardium, reaching the aortic arch clamp. Both cavae were snared. The right atriotomy was performed, while the heart was still perfused. The atrial septal stent was resected and atrial septectomy was performed. The right atriotomy was closed leaving a sump sucker in the atrium for decompression. The main PA was divided below the PA bifurcation. Two stay sutures were applied to the anterior and left lateral edge of the main PA. Then, the aortic arch clamp is was advanced toward the proximal innominate artery to continue selective cerebral perfusion. Isothermic blood cardioplegia was delivered to the ascending aorta. After cardiac arrest was instituted, the aortic arch incision was extended below to the proximal ascending aorta paying attention to the coronary orifices, and the incisions in the pulmonary root and the aorta were adjusted to an appropriate height, which would allow amalgamation of these roots without kinking of the aortic root and risk for coronary occlusion. The ascending aorta and the pulmonary root were sutured. The remaining aortic reconstruction was completed with the rest of the bovine pericardial patch. After deairing procedure, all clamps were removed and the whole body and heart perfusion were reinstituted. Duration of cardiac arrest was usually around $15 \mathrm{~min}$. During rewarming, pulmonary bands were removed. Narrowed pulmonary segments were either dilated or patch reconstructed. Proximal opening of the PA was closed primarily or with a small bovine pericardial patch. The superior vena cava was divided at the right atrial junction and anastomosed to the right PA in an end-to-side fashion. The rest of the operation was completed as usual, leaving the mediastinal and pleural drains and temporary pacing wires. The sternum was left open depending on the hemodynamic status of the patient or surgeon's preference.

\section{Postoperative management and follow-up}

After the first stage, general principles of the intensive care unit management were the identical between the groups. Typically, oxygen saturations of 75 to $85 \%$ and a hematocrit level of 40 to $45 \%$ were targeted. Sedation was used to decrease oxygen consumption. Balanced pulmonary and systemic circulations were achieved with permissive hypercapnia and low oxygen gas mixtures. All patients received vasoactive agents including milrinone, adrenaline, noradrenaline, and dopamine depending on their hemodynamic status. Contrary to the Norwood operations in which the patients were kept sedated until the sternum was closed, we attempted to extubate the patients after the hybrid procedure as early as possible.

Follow-up was completed for all patients. After discharge following the first stage, echocardiographic 


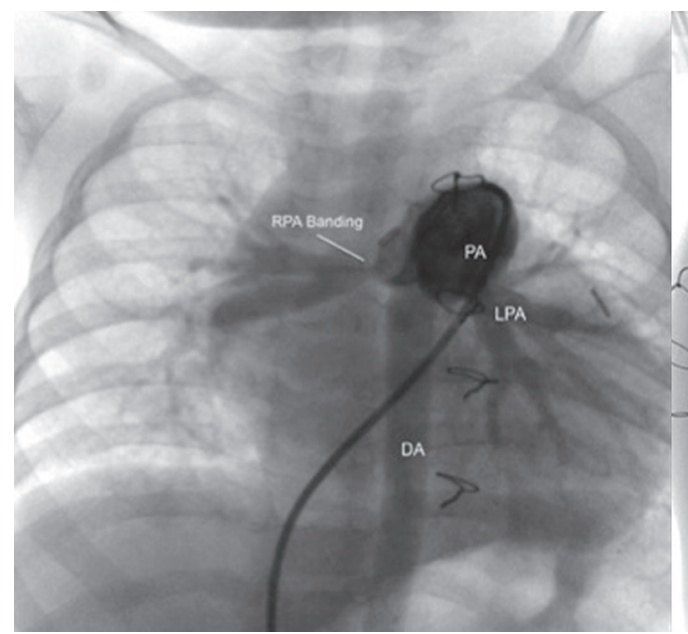

Anterior view

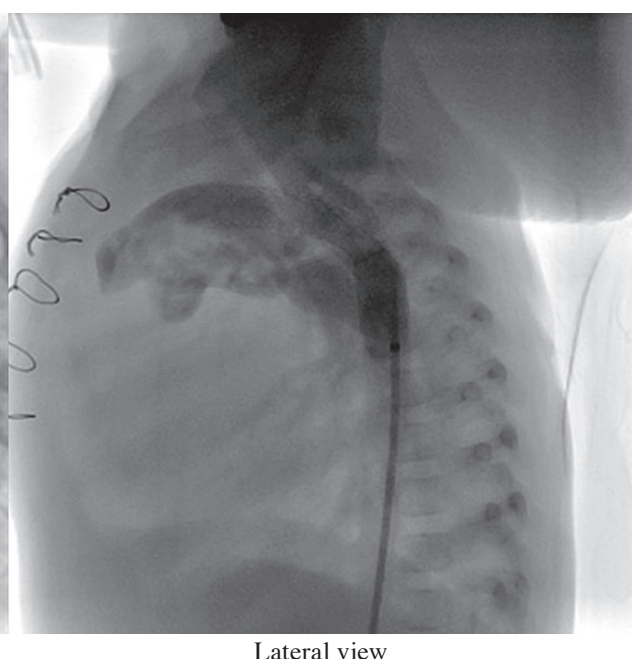

Lateral view

Figure 1. An angiographic view before comprehensive Stage II procedure.

examinations were performed at two-week intervals, whenever possible. All patients underwent heart catheterization and/or computed tomography angiography before Stage II and Stage III (Figures 1 and 2). Acetylsalicylic acid was the standard medicine after all stages for all patients.

\section{Statistical analysis}

Statistical analysis was performed using the $\mathrm{R}$ package version 3.5.2 (R Development Core Team, IBM Corp., NY, USA). Descriptive data were expressed in median (min-max) or number and frequency. Normality for continuous variables was tested using

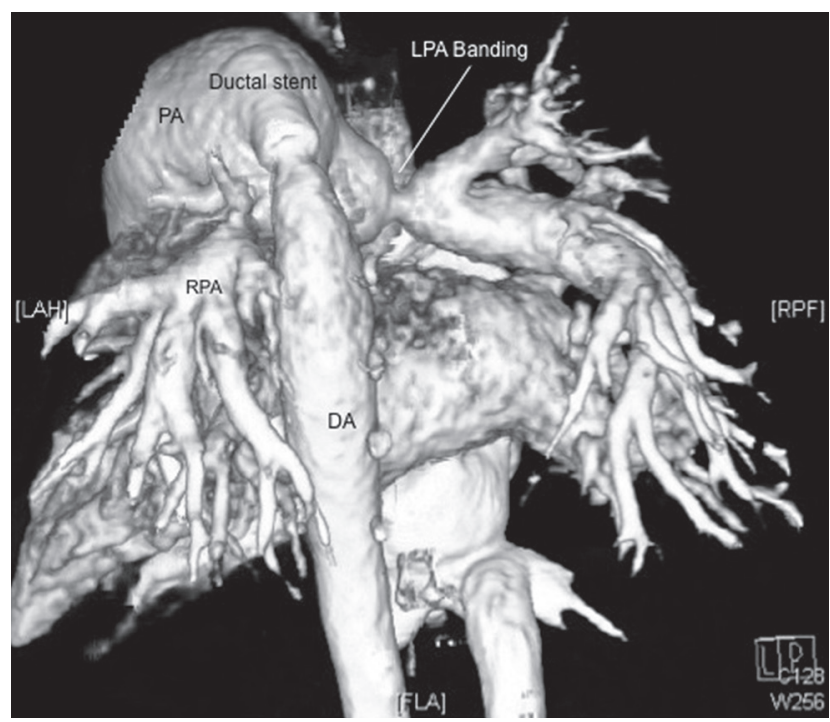

Figure 2. A computed tomography angiography view before comprehensive Stage II. the Shapiro-Wilk test. The Mann-Whitney U test was used to compare the two groups in terms of continuous variables. The chi-square test of independence was used to examine relationships between categorical variables. The Fisher's exact test was used, when the assumption of expected counts being at least 5 for chi-square test of independence was not satisfied. Univariate and multivariate logistic regression analysis was used to analyze the relationship between explanatory variables and binary outcomes. The Kaplan-Meier survival probabilities were computed and plotted to compare treatment groups in terms of mortality risk. Survival curves were compared using the log-rank test. A $p$ value of $<0.05$ was considered statistically significant.

\section{RESULTS}

The median body weight in Group $\mathrm{H}$ was significantly lower and the number of patients with a low birth weight $(<2,500 \mathrm{~g})$ was significantly higher than Group N ( $\mathrm{p}=0.002$ and 0.004 , respectively). The rate of postoperative early mortality was not statistically different between the groups $(\mathrm{n}=15 ; 46.8 \%$ in Group $\mathrm{N}$ vs. $n=27 ; 41.5 \%$ in Group $H ; p=0.62)$. Eleven of the patients (34.3\%) in Group $\mathrm{N}$ needed extracorporeal membrane oxygenation (ECMO) support (perioperative $\mathrm{n}=3$; extracorporeal cardiopulmonary resuscitation [ECPR] $n=3$ and postoperative $n=5$ ). Only one of them $(9 \%)$ requiring postoperative ECMO survived. Five patients $(26.3 \%)$ died after a long duration of mechanical ventilation ( $>7$ days) due to sepsis or multiorgan failure (MOF). Eight of the surviving patients (47\%) in Group $\mathrm{N}$ needed a long duration of mechanical ventilation. All patients had delayed 
Table 1. Baseline demographic and clinical characteristics of study population

\begin{tabular}{|c|c|c|c|c|c|c|c|c|c|}
\hline & \multicolumn{4}{|c|}{ Norwood (n=32) } & \multicolumn{4}{|c|}{ Hybrid $(n=65)$} & \multirow[b]{2}{*}{$p$} \\
\hline & $\mathrm{n}$ & $\%$ & Median & Min-Max & $\mathrm{n}$ & $\%$ & Median & Min-Max & \\
\hline Age (day) & & & 5 & $1-25$ & & & 6 & $1-55$ & 0.32 \\
\hline $\begin{array}{l}\text { Gender } \\
\text { Male } \\
\text { Female }\end{array}$ & $\begin{array}{c}28 \\
4\end{array}$ & & & & $\begin{array}{l}44 \\
21\end{array}$ & & & & 0.06 \\
\hline HLHC & 4 & 12.5 & & & 19 & 29.2 & & & 0.12 \\
\hline Body weight (g) & & & 3,200 & $2,700-3,700$ & & & 3,000 & $1,500-3,900$ & $0.002 *$ \\
\hline Body weight $<2,500 \mathrm{~g}$ & 0 & 0 & & & 14 & 21.5 & & & $0.004 *$ \\
\hline Preoperative intubation & 10 & 31.5 & & & 29 & 44.6 & & & 0.30 \\
\hline Syndromic condition & 2 & 6.2 & & & 3 & 4.6 & & & 1 \\
\hline Preoperative MOF & 3 & 9.3 & & & 8 & 12.3 & & & 1 \\
\hline Asc $A o>3 \mathrm{~mm}$ & 4 & 12.5 & & & 5 & 7.6 & & & 0.47 \\
\hline
\end{tabular}

Min: Minimum; Max: Maximum; HLHC: Hypoplastic left heart complex; MOF: Multiorgan failure; Asc Ao: Ascending aorta; $*$ p $<0.05$.

sternal closure and intraoperative peritoneal dialysis catheters, which were usually used to provide negative fluid balance in Group N. Vacuum-assisted closure therapy was applied to seven patients $(21.8 \%)$ due to difficulty in sternal closure or positive wound cultures. Baseline demographic and clinical characteristics of study population are shown in Table 1 .

The number of the patients who experienced sudden cardiac arrest and cardiopulmonary resuscitation in the early postoperative period was higher in Group $\mathrm{H}$ than Group N ( $=20 ; 30.7 \%$ vs. $n=3 ; 9.3 \% ; \mathrm{p}=0.028)$. Only two patients needed delayed sternal closure in Group $\mathrm{H}$; however, three more patients had secondary sternal opening due to hemodynamic compromise (Table 2).

Ductal stenting was unable to be performed in 12 patients due to low birth weight, unsuitable clinical condition, or early death. Three patients did not need ductal stenting, as no narrowing was detected in the patent ductus arteriosus, despite cessation of PGE1 infusion. Ductal stent migration occurred in three patients $(5.6 \%)$ in the catheterization laboratory. Two of them underwent emergent Norwood conversion, but all died. Iliac artery perforation was observed in one $(1.8 \%)$ patient causing immediate cardiac arrest and death, eventually. Four patients (7.5\%) underwent second ductal stent implantation due to narrowing during follow-up.

Atrial septal intervention was performed in 10 patients (balloon atrial septostomy $[\mathrm{BAS}] \mathrm{n}=5$; atrial septal stenting $\mathrm{n}=5)$. One patient $(20 \%)$ experienced atrial stent migration and emergent atrial septectomy, and stent removal was performed.

Table 2. Early postoperative outcomes after Stage I operations

\begin{tabular}{|c|c|c|c|c|c|}
\hline & \multicolumn{2}{|c|}{ Norwood $(n=32)$} & \multicolumn{2}{|c|}{ Hybrid $(n=65)$} & \multirow[b]{2}{*}{$p$} \\
\hline & $\mathrm{n}$ & $\%$ & $\mathrm{n}$ & $\%$ & \\
\hline Early mortality & 15 & 46.8 & 27 & 41.5 & 0.62 \\
\hline Delayed sternal closure & 32 & 100 & 5 & 7.6 & $<0.001 *$ \\
\hline Long duration of intubation ( $>7$ days) & 19 & 67.8 & 27 & 50 & 0.27 \\
\hline Sternal VAC & 7 & 25 & 2 & 3.7 & $0.01 *$ \\
\hline Cardiopulmonary resuscitation & 3 & 9.3 & 20 & 30.7 & $0.028 *$ \\
\hline Extracorporeal membrane oxygenation & 11 & 34.3 & 2 & 3.0 & $<0.001^{*}$ \\
\hline
\end{tabular}

VAC: vacuum-assisted closure; $* \mathrm{p}<0.05$. 
The ECMO support was done in two patients (3.0\%) in Group H due to ECPR. Both were unable to be weaned off and died. Prolonged mechanical ventilation was needed in 27 patients $(50 \%)$ in Group H. Causes of death in this group were sudden cardiac arrest in 11 (16.9\%), low cardiac output in five $(7.6 \%)$, cerebral hemorrhage in one $(1.5 \%)$, aspiration in one $(1.5 \%)$, and sepsis and MOF in nine patients $(13.8 \%)$.

Both univariate and multivariate analyses revealed that the need for preoperative mechanical ventilation was a significant factor for postoperative death ( $p=0.004$ and 0.003 , respectively). Syndromic appearance was also a significant factor in the multivariate analysis $(\mathrm{p}=0.03)$. The prognosis of patients with the diagnosis of HLHC was 3.6 times better than the other patients (Tables 3 and 4).

\section{Inter-stage period}

Between the first and second stage, three of the remaining 17 patients (17.6\%) required an additional procedure in Group $\mathrm{N}$ due to recurrent aortic coarctation. Two of them underwent balloon aortic angioplasty successfully and one underwent surgical coarctation repair with a separate left thoracotomy incision. Nevertheless, 13 of the remaining 38 patients (34.2\%) needed an additional intervention in Group $\mathrm{H}(\mathrm{p}=0.22)$. Five of them underwent surgical atrial septectomy due to atrial septal restriction and secondary pulmonary venous hypertension. In seven of them, Norwood conversion was performed due to suboptimal hemodynamic condition such as inability to gain weight, tachypnea, atrial septal restriction, ductal stent stenosis, or retrograde aortic coarctation. Four patients underwent ductal re-stenting due to ductal stent narrowing. There were statistically significant differences between the

Table 3. Univariate logistic regression analysis results for mortality after Stage I operations

\begin{tabular}{|c|c|c|c|c|c|}
\hline Variable & Parameter & Estimate & Standard error & $\mathrm{Z}$ & $p$ \\
\hline \multirow[t]{2}{*}{ Age } & $\beta \_0$ & -0.03 & 0.31 & -0.09 & 0.93 \\
\hline & B_1 & -0.03 & 0.03 & -1.00 & 0.32 \\
\hline \multirow[t]{2}{*}{ Weight (g) } & $\beta \_0$ & 1.86 & 1.49 & 1.25 & 0.21 \\
\hline & $\beta \_1$ & -0.001 & 0.001 & -1.45 & 0.15 \\
\hline Categorized weight & $\beta \_0$ & 0.29 & 0.54 & 0.53 & 0.59 \\
\hline$(\leq 2,500$ reference category $)$ & $\beta \_1$ & -0.65 & 0.58 & -1.12 & 0.26 \\
\hline Gender & $\beta \_0$ & -0.22 & 0.24 & -0.94 & 0.35 \\
\hline (Male reference category) & $\beta \_1$ & -0.18 & 0.47 & -0.39 & 0.70 \\
\hline Diagnosis & $\beta \_0$ & -1.28 & 0.51 & -2.53 & $0.01^{*}$ \\
\hline (HLHC reference category) & $\beta \_1$ & 1.28 & 0.56 & 2.30 & $0.02^{*}$ \\
\hline Preoperative intubation & $\beta \_0$ & -0.80 & 0.28 & -2.81 & $0.01^{*}$ \\
\hline (no is reference category) & $\beta \_1$ & 1.27 & 0.44 & 2.92 & $0.004 *$ \\
\hline Syndromic conditions & $\beta \_0$ & -0.35 & 0.21 & -1.66 & 0.10 \\
\hline (no is reference category) & $\beta \_1$ & 1.74 & 1.14 & 1.53 & 0.13 \\
\hline General conditions & $\beta \_0$ & -0.33 & 0.22 & -1.50 & 0.13 \\
\hline (not bad is reference category) & $\beta \_1$ & 0.51 & 0.64 & 0.79 & 0.43 \\
\hline Ascending aorta $>3 \mathrm{~mm}$ & $\beta \_0$ & -0.14 & 0.21 & -0.64 & 0.52 \\
\hline (no is reference category) & $\beta \_1$ & -1.94 & 1.08 & -1.80 & 0.07 \\
\hline First surgery & $\beta \_0$ & -0.34 & 0.25 & -1.36 & 0.18 \\
\hline (Hybrid is reference category) & $\beta \_1$ & 0.22 & 0.44 & 0.50 & 0.62 \\
\hline
\end{tabular}

HLHC: Hypoplastic left heart complex; *: p<0.05. 
Table 4. Multivariate logistic regression analysis results for mortality after Stage I operations

\begin{tabular}{ccccc}
\hline Variable & Estimate & Standard error & $\mathrm{Z}$ & $p$ \\
\hline 1 & -2.60 & 2.09 & -1.24 & 0.21 \\
2 & -0.03 & 0.05 & -0.73 & 0.46 \\
3 & 0.0002 & 0.0006 & 0.38 & 0.70 \\
4 & 0.28 & 0.58 & 0.49 & 0.62 \\
5 & 1.42 & 0.78 & 1.82 & 0.07 \\
6 & 1.70 & 0.57 & 2.97 & $0.003^{*}$ \\
7 & 3.20 & 1.48 & 2.17 & $0.03^{*}$ \\
8 & -1.42 & 0.90 & -1.58 & 0.11 \\
9 & -1.29 & 1.16 & -1.12 & 0.26 \\
10 & 0.17 & 0.54 & 0.31 & 0.76 \\
\hline
\end{tabular}

groups in terms of inter-stage mortality $(3 / 17,17.6 \%$ in Group N; 18/38, 47.3\% in Group H) ( $\mathrm{p}=0.0045)$. Most of the deaths were sudden death at home or after additional procedures in the hospital setting.

\section{Second stage}

Second-stage procedure was performed to 32 patients. The median age at the time of the second procedure was 7.5 (range, 6 to 17) months. Thirteen of them underwent bidirectional Glenn operation in Group N. Three of them had additional aortic patch replacement due to aneurysmal degeneration of CorMatrix (small intestinal submucosa extracellular matrix; CorMatrix Cardiovascular Inc., GA, USA) patch (Figure 3). ${ }^{[12]}$ One patient had additional tricuspid valve annuloplasty. Fourteen of the patients $(21.5 \%)$ in Group H had comprehensive Stage II (Norwood+Glenn) operation and five of the patients $(7.6 \%)$ with the diagnosis of HLHC in Group H underwent biventricular repair. The details of these patients were published elsewhere. ${ }^{[13]}$ Early mortality after Glenn operation was $7.6 \%(n=1)$. This patient had also an aortic aneurysm due to a degenerated CorMatrix patch, and aortic patch replacement was also performed. Although early postoperative period was uneventful, the patient had sudden cardiac arrest on postoperative Day 1. The patient died on postoperative Day 40 due to MOF, despite successfully weaning from ECPR support.

Six patients $(42.8 \%)$ died after comprehensive Stage II operation $(p=0.06)$. Two of them $(14.2 \%)$ experienced low cardiac output and died of MOF, despite ECMO support. One patient (7.1\%) had sudden cardiac arrest on postoperative Day 2 and died, despite ECPR support. In three of them, vena cava superior (VCS) syndrome developed due to a high PA pressure. Left PA stent implantation was performed with some relief in two patients (14.2\%). However, these patients died of sepsis after prolonged hospitalization. Another patient with VCS syndrome underwent Glenn take-down procedure and Sano shunt was performed. Perioperative ECMO support was needed and the patient died of cerebral hemorrhage. A total of four patients experienced VCS syndrome after comprehensive Stage II operation, while four patients needed left PA stent implantation.

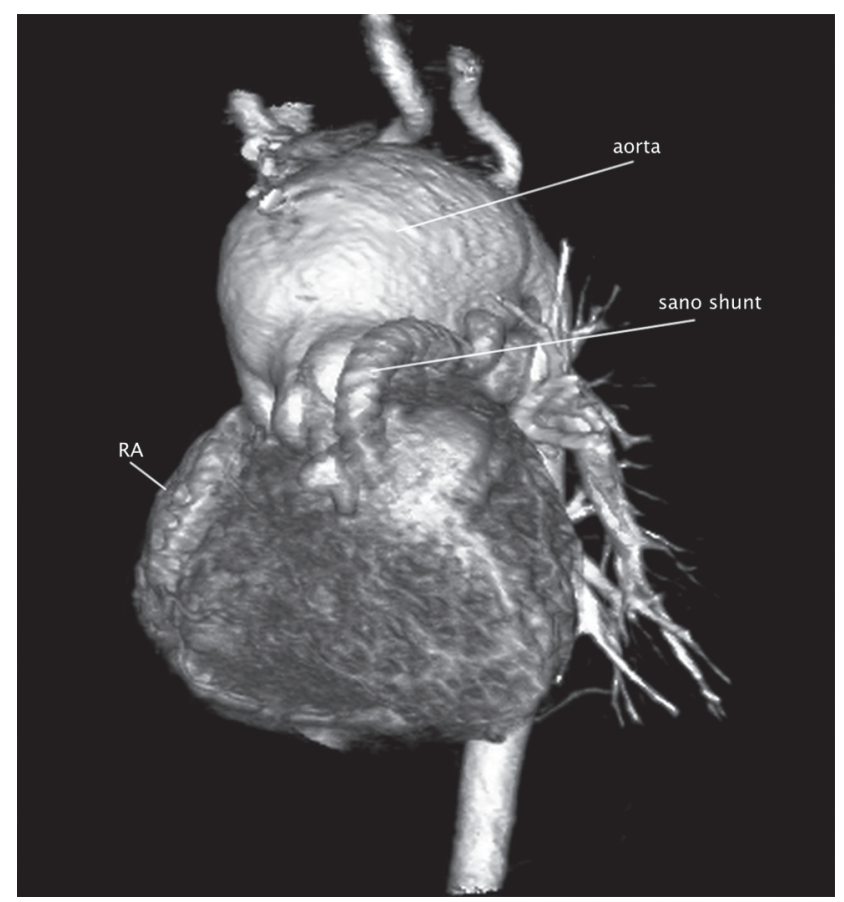

Figure 3. A computed tomography angiography view in a patient with an aortic aneurysm due to CorMatrix patch. 


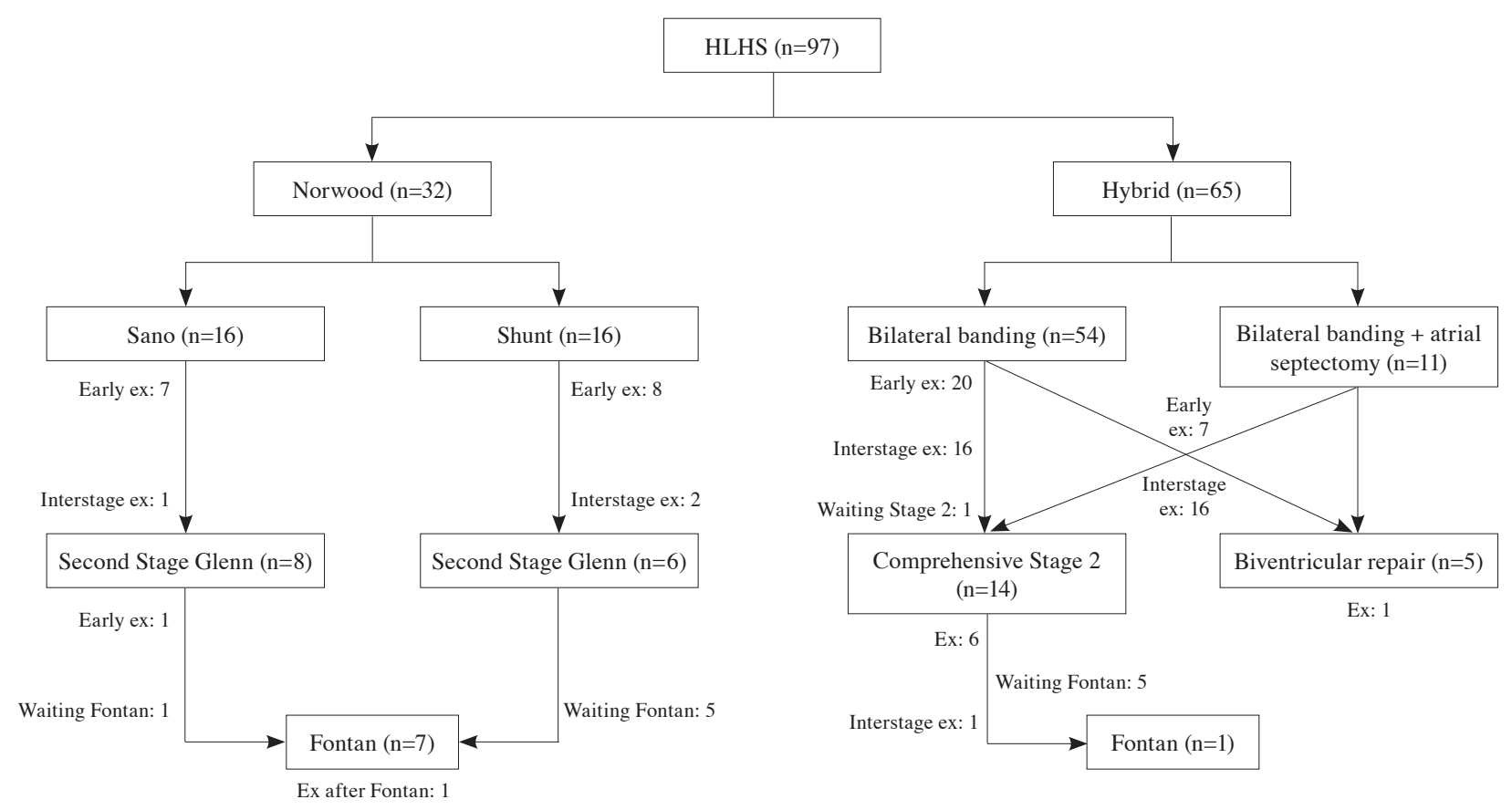

Figure 4. Summary of the patients' outcomes.

HLHC: Hypoplastic left heart complex.

Prolonged length of hospitalization (>30 days) was needed in two (15.3\%) and eight $(57.1 \%)$ patients in Group $\mathrm{N}$ and $\mathrm{H}$, respectively ( $\mathrm{p}=0.046$ ).

\section{Third stage}

A total of eight patients underwent third-stage fenestrated extracardiac Fontan operation. Seven patients were in Group $\mathrm{N}$ and one patient was in Group H. One patient (12.5\%) in Group N died after operation. Although ECMO support was provided due to low cardiac output state in the early postoperative period, the patient died of MOF during the ECMO support. Other patients had an uneventful postoperative course (Figure 4).

The Kaplan-Meier actuarial survival probability of the groups are shown in Figure 5. Group N demonstrated better survival curve $(37.5 \%$ at one year; $32.5 \%$ at five years vs. $20 \%$ at one year; $15 \%$ at five years, respectively), although the difference was not statistically significant $(\mathrm{p}=0.15)$. Subgroup analysis showed that the Norwood procedure with Sano modification had the highest survival curve (40\% at five years) (Figure 6).

\section{DISCUSSION}

In patients with HLHS and its variants, our analysis of baseline characteristics showed that hybrid procedures might be selected for Stage I palliation in high-risk neonates and low-birth-weight patients. A small survival advantage of hybrid procedures early after Stage I was demolished with high inter-stage and second-stage mortality and morbidity rates.

Although some centers reported up to $95 \%$ survival rates with hybrid interventions ${ }^{[14]}$ head-to-head studies comparing hybrid and Norwood approaches are limited. A recent multi-center study of the Congenital Heart Surgeons' Society (CHSS) compared hybrid and Norwood procedures in 564 patients. ${ }^{[15]}$ Risk-adjusted four-year survival was higher after the Norwood with Sano modification than the Norwood with BlalockTaussig (BT) shunt or hybrid $(76 \%$ vs. $60 \%$ vs. $61 \%$, respectively; $\mathrm{p}<0.001)$. Furthermore, for neonates with a lower birth weight $(<2,000 \mathrm{~g})$, an interaction between birth weight and hybrid resulted in a trend toward improved survival after hybrid, compared to the Norwood modifications. For propensity-matched neonates between hybrid and Norwood with BT shunt (88 pairs), four-year survival was similar (62\% vs. $57 \%$, respectively; $p=0.58$ ). For propensity-matched neonates between hybrid and Norwood with Sano modification (81 pairs), four-year survival was improved after the Norwood with Sano modification (59\% vs. $75 \%$, respectively; $\mathrm{p}=0.008) .^{[15]}$ In our study, however, we 


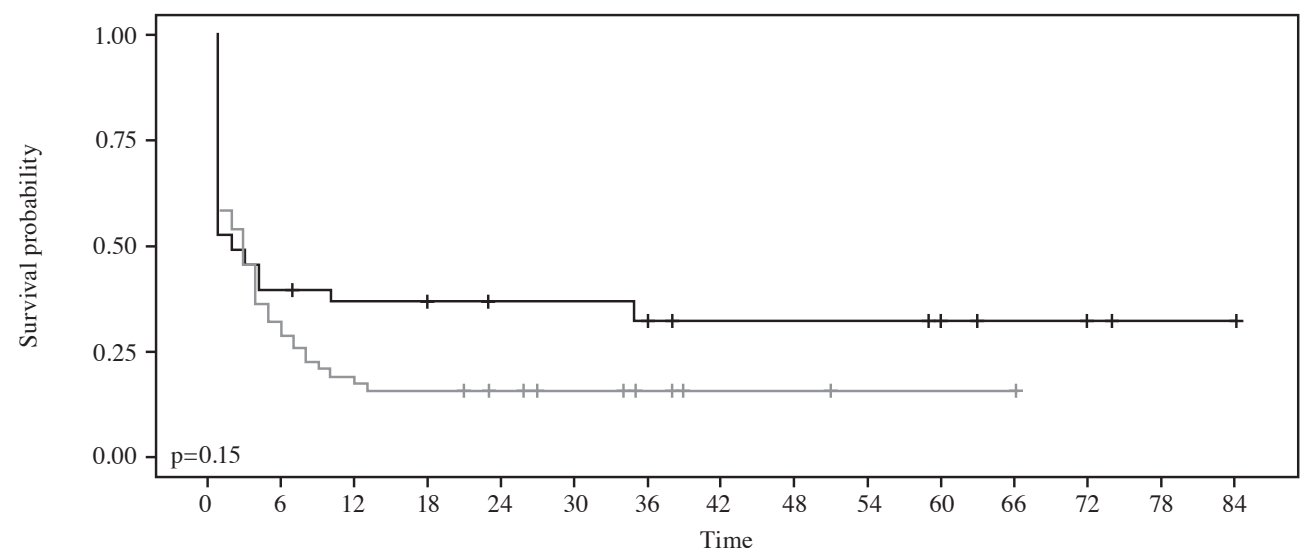

\begin{tabular}{|c|c|c|c|c|c|c|c|c|c|c|c|c|c|c|c|}
\hline \multirow{4}{*}{$\begin{array}{l}\text { Hybrid } \\
\stackrel{\Xi}{ت} \text { N Norwood }\end{array}$} & \multicolumn{15}{|c|}{ Number at risk } \\
\hline & 65 & 21 & 13 & 11 & 9 & 7 & 4 & 2 & 2 & 1 & 1 & 1 & 0 & 0 & 0 \\
\hline & 32 & 13 & 11 & 11 & 9 & 9 & 8 & 6 & 6 & 6 & 5 & 3 & 3 & 1 & 1 \\
\hline & 0 & 6 & 12 & 18 & 24 & 30 & 36 & 42 & 48 & 54 & 60 & 66 & 72 & 78 & 84 \\
\hline
\end{tabular}

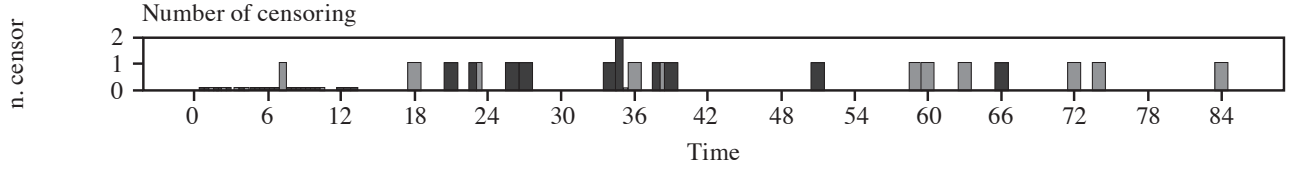

+ Hybrid + Norwood

Figure 5. Kaplan-Meier actuarial survival probability of study groups.

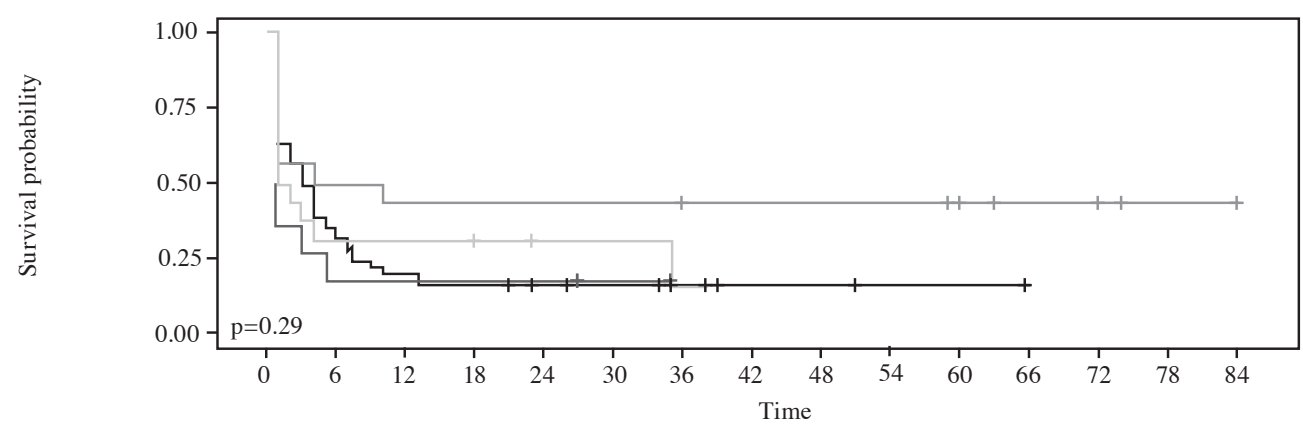

\begin{tabular}{|c|c|c|c|c|c|c|c|c|c|c|c|c|c|c|c|}
\hline \multirow{6}{*}{$\begin{array}{r}\text { Hybrid } \\
\text { Hyb }+ \text { Sep } \\
\text { Sano } \\
\text { Shunt }\end{array}$} & \multicolumn{15}{|c|}{ Number at risk } \\
\hline & 54 & 19 & 11 & 9 & 7 & 6 & 4 & 2 & 2 & 1 & 1 & 1 & 0 & 0 & 0 \\
\hline & 11 & 2 & 2 & 2 & 2 & 1 & 0 & 0 & 0 & 0 & 0 & 0 & 0 & 0 & 0 \\
\hline & 16 & 8 & 7 & 7 & 7 & 7 & 7 & 6 & 6 & 6 & 5 & 3 & 3 & 1 & 1 \\
\hline & 16 & 5 & 4 & 4 & 2 & 2 & 1 & 0 & 0 & 0 & 0 & 0 & 0 & 0 & 0 \\
\hline & $\begin{array}{l}1 \\
0\end{array}$ & 6 & 12 & 18 & 24 & 30 & 36 & 42 & 48 & 54 & 60 & 66 & 72 & 78 & 84 \\
\hline
\end{tabular}

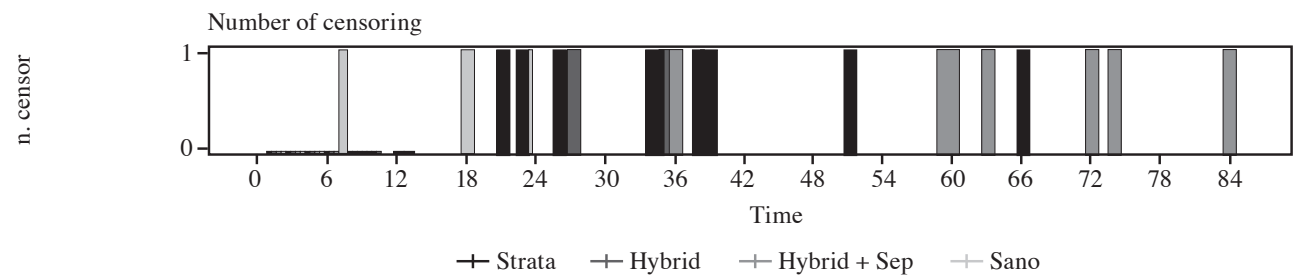

Figure 6. Kaplan Meier actuarial survival probability of subgroups. 
had no patient who underwent Norwood modifications below a body weight of $2,700 \mathrm{~g}$, while there were 14 patients in the hybrid group below a body weight of 2,500 g (the smallest case was 1,500 g). Low-birthweight has been shown to be associated with high operative mortality after the Norwood modifications in many studies. ${ }^{[15-17]}$ That is why we chose hybrid procedure for neonates below 2,500 g. We believe that hybrid procedure is the most optimal option and the only alternative for these patients. Due to the high rate of potential complications of ductal stenting in premature infants, we usually continue PGE1 infusion, until patients reach over $2,500 \mathrm{~g}$.

Parallel to the CHSS study, our study demonstrated that the Norwood with Sano modification was associated with the most improved overall survival. A possible explanation can be related to the difference of coronary artery perfusion. ${ }^{[18]}$ The greatest part of coronary artery perfusion occurs during diastole. Continuous, forward pulmonary artery flow through the BT shunt may cause diastolic run-off, which is associated with coronary artery insufficiency and decreased myocardial perfusion. ${ }^{[18,19]}$ The physiology after the hybrid procedure is also similar to that after BT shunt. In contrast, the physiology after the Sano modification eliminates the possibility of diastolic run-off away from the coronary circulation, thereby, potentially resulting in better myocardial perfusion. ${ }^{[20]}$ The results of the Pediatric Heart Network Single Ventricle Reconstruction Trial also support that the difference in coronary artery perfusion may be an important factor contributing to the early difference in survival rates between the Sano and BT shunt modifications ( $74 \%$ vs. $64 \%$, respectively). ${ }^{[21]}$

The main advantages of hybrid procedure are avoidance of the adverse effects of CPB and deep hypothermic circulatory arrest or regional cerebral perfusion during the fragile neonatal period with shorter operation and hospitalization times and better potential neurological outcomes. ${ }^{[5-7]}$ The disadvantages are, however, the concerns about the PA growth, risk for retrograde coarctation, difficulty in atrial septal manipulation, and increased inter-stage intervention rates. ${ }^{[8-10,15]}$ Our hybrid procedure experience started with the patients in poor clinical condition. Initial promising results motivated us to use this strategy for all patients. Although the present study is the sum of the all patients with the initial learning period, we were unable to show any survival benefit in favor of hybrid strategy. Contrarily, management of the patients after hybrid intervention was much more difficult than the patients after the Norwood operation. Several patients experienced sudden death at home mostly after crying. We believe that hybrid patients need a very close follow-up (weekly, if applicable) and also home monitoring with oxygen saturation, respiratory rate, and weight gain measurements. In case of any suspicion, hospitalization, comprehensive examination and intervention, when necessary, should be performed. ${ }^{[22]}$ In our study, we were unable to make properly these preventive follow-up programs due to the patients living other cities or scarcity of the resources.

Atrial septum is usually thick and its alignment may be different in patients with HLHS. That is why transcatheter BAS is usually ineffective in these cases. ${ }^{[1,5,14]}$ We performed BAS in five patients with some success; however, the recurrent restriction rate was high. During the inter-stage period, we observed progressive residual or recurrent atrial septal restriction causing severe pulmonary venous hypertension, heart failure, and failure to thrive. Based on our experiences, inter-stage atrial septectomy has a high mortality rate. Atrial septal stent implantation was applied to these patients, due to the drawbacks of atrial septal manipulation. According to our limited experience in five patients, however, atrial stent implantation is not easy during catheterization laboratory and malposition and migration of stents are the main concerns. Similarly, one patient needed emergency surgery due to stent migration in our series. Due to the difficulty of atrial septal manipulation, we performed surgical atrial septectomy in 11 patients with a restricted atrial septum during bilateral banding procedure using a short period of CPB. Unfortunately, the subgroup analysis showed no survival benefit for this strategy, either.

According to our experience, comprehensive Stage II procedure has a high mortality and morbidity rate, mostly due to PA developmental problems or high residual PA pressures. In our study, left PAs usually had residual stenoses after de-banding. Compression of enlarged neoaortic roots might be an explanation. Intraoperative left PA stenting is a common practice during comprehensive Stage II operation. ${ }^{[14,15]} \mathrm{We}$ were unable to make any objective measurement of the branch PAs and make a comparison between the groups, but although Latus et al. ${ }^{[23]}$ showed that the PA size was reduced (lower lobe index 135 \pm 74 vs. $161 \pm 62 \mathrm{~mm}^{2} / \mathrm{m}^{2}$, respectively; $\mathrm{p}=0.02$ ) and the reintervention rate was significantly higher in the hybrid group, compared to the Norwood patients.

In our study, the patients who underwent the Norwood procedure had a more uneventful course of 
inter-stage period, Stage II and III, despite drawbacks early after Stage I procedure. We, therefore, quitted to perform hybrid procedure in patients who are good candidates for the Norwood operation. In our routine practice, we perform the hybrid intervention in patients with HLHS with a poor clinical condition or whose body weight is under $<2,500 \mathrm{~g}$.

We believe that hybrid strategy is very useful for patients who are candidates for further complex biventricular repairs. These patients usually need an extensive neonatal procedure with high mortality and morbidity or even difficult to decide for them whether biventricular repair may be performed. The hybrid procedure provides to avoid neonatal high-risk surgery in these patients and delays the difficult decision for biventricular repair to a later stage. Development of the left heart structures with time may also facilitate the decision and enhance the possibility of biventricular repair. ${ }^{[24,25]}$ Besides, some concerns of hybrid procedure such as retrograde aortic coarctation, atrial septal defect restriction, and risk for coronary ischemia due to lack of the antegrade aortic flow usually do not exist in this group of patients.

The main limitations of the present study are its retrospective nature, relatively small sample size, and inclusion of the learning curve.

In conclusion, although our results are less prominent than current practice in developed countries, it has been improving with increased experience. However, more resources are still needed for hospital readmissions, hospitalizations, interventions, and home monitoring services. Based on our experiences, the Norwood with Sano modification had the highest survival rate and hybrid procedure may be reserved for patients with a low birth weight and poor clinical condition.

\section{Acknowledgement}

We thank Ozgur Asar for his invaluable statistical assistance.

\section{Declaration of conflicting interests}

The authors declared no conflicts of interest with respect to the authorship and/or publication of this article.

\section{Funding}

The authors received no financial support for the research and/or authorship of this article.

\section{REFERENCES}

1. Roeleveld PP, Axelrod DM, Klugman D, Jones MB, Chanani NK, Rossano JW, et al. Hypoplastic left heart syndrome: from fetus to fontan. Cardiol Young 2018;28:1275-88.
2. Ohye RG, Schranz D, D'Udekem Y. Current Therapy for Hypoplastic Left Heart Syndrome and Related Single Ventricle Lesions. Circulation 2016;134:1265-79.

3. Pizarro C, Malec E, Maher KO, Januszewska K, Gidding $\mathrm{SS}$, Murdison KA, et al. Right ventricle to pulmonary artery conduit improves outcome after stage I Norwood for hypoplastic left heart syndrome. Circulation 2003;108:II155-60.

4. Turek JW, Hanfland RA, Davenport TL, Torres JE, Duffey DA, Patel SS, et al. Norwood reconstruction using continuous coronary perfusion: a safe and translatable technique. Ann Thorac Surg 2013;96:219-23.

5. Caldarone CA, Benson L, Holtby H, Li J, Redington AN, Van Arsdell GS. Initial experience with hybrid palliation for neonates with single-ventricle physiology. Ann Thorac Surg 2007;84:1294-300.

6. Akintürk H, Michel-Behnke I, Valeske K, Mueller M, Thul $\mathrm{J}$, Bauer J, et al. Hybrid transcatheter-surgical palliation: basis for univentricular or biventricular repair: the Giessen experience. Pediatr Cardiol 2007;28:79-87.

7. Galantowicz M, Cheatham JP, Phillips A, Cua CL, Hoffman TM, Hill SL, et al. Hybrid approach for hypoplastic left heart syndrome: intermediate results after the learning curve. Ann Thorac Surg 2008;85:2063-70.

8. Honjo O, Benson LN, Mewhort HE, Predescu D, Holtby H, Van Arsdell GS, et al. Clinical outcomes, program evolution, and pulmonary artery growth in single ventricle palliation using hybrid and Norwood palliative strategies. Ann Thorac Surg 2009;87:1885-92.

9. Venugopal PS, Luna KP, Anderson DR, Austin CB, Rosenthal E, Krasemann T, et al. Hybrid procedure as an alternative to surgical palliation of high-risk infants with hypoplastic left heart syndrome and its variants. J Thorac Cardiovasc Surg 2010;139:1211-5.

10. Baba K, Kotani Y, Chetan D, Chaturvedi RR, Lee KJ, Benson LN, et al. Hybrid versus Norwood strategies for single-ventricle palliation. Circulation 2012;126:S123-31.

11. Yörüker U, Akintürk H. Giessen procedure as comprehensive stage II palliation with aortic arch reconstruction after hybrid bilateral pulmonary artery banding and ductal stenting for hypoplastic left heart syndrome. Semin Thorac Cardiovasc Surg Pediatr Card Surg Annu 2018:19-27.

12. Erek E, Aydin S, Suzan D, Yildiz O, Demir IH, Odemis E. Early Degeneration of Extracellular Matrix Used for Aortic Reconstruction During the Norwood Operation. Ann Thorac Surg 2016;101:758-60.

13. Erek E, Suzan D, Aydin S, Temur B, Demir IH, Odemis E. Staged biventricular repair after hybrid procedure in highrisk neonates and infants. World J Pediatr Congenit Heart Surg 2019;10:426-32.

14. Schranz D, Bauer A, Reich B, Steinbrenner B, Recla S, Schmidt D, et al. Fifteen-year single center experience with the "Giessen Hybrid" approach for hypoplastic left heart and variants: current strategies and outcomes. Pediatr Cardiol 2015;36:365-73.

15. Wilder TJ, McCrindle BW, Hickey EJ, Ziemer G, Tchervenkov CI, Jacobs ML, et al. Is a hybrid strategy 
a lower-risk alternative to stage 1 Norwood operation? J Thorac Cardiovasc Surg 2017;153:163-72.e6.

16. Bové T, François K, De Groote K, Suys B, De Wolf D, Verhaaren $\mathrm{H}$, et al. Outcome analysis of major cardiac operations in low weight neonates. Ann Thorac Surg 2004;78:181-7.

17. Hickey EJ, Nosikova Y, Zhang H, Caldarone CA, Benson L, Redington A, et al. Very low-birth-weight infants with congenital cardiac lesions: is there merit in delaying intervention to permit growth and maturation? J Thorac Cardiovasc Surg 2012;143:126-36, 136.e1.

18. Donnelly JP, Raffel DM, Shulkin BL, Corbett JR, Bove EL, Mosca RS, et al. Resting coronary flow and coronary flow reserve in human infants after repair or palliation of congenital heart defects as measured by positron emission tomography. J Thorac Cardiovasc Surg 1998;115:103-10.

19. DeCampli WM, Tsai FW, Argueta-Morales IR, Smith C, Munro HM. The effect of epinephrine on coronary flow in the setting of a systemic-to-pulmonary artery shunt. World J Pediatr Congenit Heart Surg 2013;4:373-9.

20. Sano S, Ishino K, Kawada M, Arai S, Kasahara S, Asai T, et al. Right ventricle-pulmonary artery shunt in first-stage palliation of hypoplastic left heart syndrome. J Thorac Cardiovasc Surg 2003;126:504-9.

21. Ohye RG, Sleeper LA, Mahony L, Newburger JW, Pearson $\mathrm{GD}, \mathrm{Lu} \mathrm{M}$, et al. Comparison of shunt types in the Norwood procedure for single-ventricle lesions. N Engl J Med 2010;362:1980-92.

22. Ugonabo N, Hirsch-Romano JC, Uzark K. The role of home monitoring in interstage management of infants following the Norwood procedure. World J Pediatr Congenit Heart Surg 2015;6:266-73.

23. Latus H, Nassar MS, Wong J, Hachmann P, BellshamRevell $\mathrm{H}$, Hussain $\mathrm{T}$, et al. Ventricular function and vascular dimensions after Norwood and hybrid palliation of hypoplastic left heart syndrome. Heart 2018;104:244-52.

24. Karimi M, Farouk A, Golden A, Gilkeson R. Hybrid palliation of interrupted aortic arch in a high-risk neonate. Ann Pediatr Cardiol 2010;3:74-6.

25. Ballard G, Tibby S, Miller O, Krasemann T, Rosenthal E, Anderson D, et al. Growth of left heart structures following the hybrid procedure for borderline hypoplastic left heart. Eur J Echocardiogr 2010;11:870-4. 